\title{
Pemanfaatan Daun Karamunting Sebagai Bahan Baku Tinta Spidol
}

\author{
Herliani \\ SMAN 1 Cempaga, Jalan Tjilik Riwut KM. 28 Desa Sungai Paring, Kotawaringin Timur, \\ Kalimantan Tengah, Indonesia \\ herlinchem@gmail.com
}

\begin{abstract}
Abstrak. Karamunting (Rhodomyrtus tomentosa) adalah tumbuhan liar yang keberadaannya sangat melimpah disekitar sekolah kami yang pemanfaatannya terbatas hanya sebagai obat luka menggunakan daunnya. Pada daun Karamunting terkandung beberapa senyawa metabolit sekunder,diantaranya adalah tanin. Tanin merupakan bahan pewarna pada tumbuhan yang banyak tersebar luas pada tanaman, karena itulah kami melakukan penelitian ini yaitu untuk memanfaatkan daun Karamunting sebagai bahan baku tinta spidol. Penelitian ini dilakukan secara eksperimen dengan membandingkan 3 sampel daun Karamunting yang digunakan yaitu sampel 1 bagian atas ekstrak daun Karamunting yang telah didiamkan selama 1 jam, sampel 2 bagian bawah (endapan) ekstrak daun Karamunting yang telah didiamkan selama 1 jam, dan sampel 3 daun Karamunting yang dihaluskan dan dicampur air. Masing-masing sampel ini kemudian direbus sampai mendidih, setelah dingin ditambahkan tepung kanji, paku berkarat, dan cuka kemudian dibiarkan selama 1 malam. Pemanfaatan daun Karamunting sebagai bahan baku tinta spidol dapat dilakukan. Dari pencampuran 3 sampel daun Karamunting didapatkan warna hitam yang lebih pekat pada sampel 2. Diperlukan penelitian lebih lanjut untuk menyempurnakan hasil penelitian ini.
\end{abstract}

Kata kunci: daun karamunting, tinta spidol

\section{PENDAHULUAN}

Sekolah kami merupakan salah satu Sekolah Rintisan Adiwiyata sejak tahun 2016. Hal ini membuat kami selaku warga sekolah menyelenggarakan berbagai kegiatan yang sesuai dengan tujuan program tersebut yaitu mewujudkan warga sekolah yang bertanggung jawab dalam upaya perlindungan dan pengelolaan lingkungan hidup melalui tata kelola sekolah yang baik untuk mendukung pembangunan berkelanjutan. Untuk mendukung tujuan program Adiwiyata tersebut, maka ditetapkan 4 komponen program yang menjadi satu kesatuan utuh dalam mencapai Sekolah Adiwiyata, salah satunya yaitu pengelolaan sarana pendukung ramah lingkungan.

Penggunaan spidol sebagai alat tulis ketika kegiatan PBM sudah sangat lazim. Banyaknya konsumsi tinta isi ulang spidol dikarenakan banyaknya kelas yang menggunakan sudah tentu menimbulkan dampak baik bagi kesehatan dan pembiayaan. Program Sekolah Rintisan Adiwiyata membuat kami harus menerapkan pengelolaan sarana pendukung ramah lingkungan serta melakukan penghematan dari aspek manapun.

Sekolah kami berada disebuah kecamatan yang letaknya $28 \mathrm{KM}$ dari ibukota kabupaten, tepatnya di SMAN 1 Cempaga, Kecamatan Cempaga Kabupaten Kotawaringin Timur. Sepanjang perjalanan dari rumah menuju sekolah dan disekitar lingkungan sekolah kami banyak ditumbuhi tanaman semak belukar, salah satunya yaitu tanaman Karamunting (Rhodomyrtus tomentosa). Tanaman 
yang berasal dari Asia Selatan dan Tenggara ini banyak tersebar di daerah subtropis dan tropis sehingga tidak heran tanaman ini begitu banyak dijumpai di sekitar sekolah kami. Tanaman ini hanya dibiarkan tumbuh bebas dan sekali waktu kami pangkas karena tanaman ini sangat cepat perkembangannya karena dapat hidup diberbagai habitat dan segala jenis tanah.

Tanaman ini tidak pernah kami manfaatkan kecuali bunganya yang terlihat indah sebagai tanaman hias dan sebagai obat luka menggunakan daunnya. Karena itulah kami mencoba memanfaatkan bagian tanaman ini sehingga dapat diolah menjadi produk yang bermanfaat. Setelah mencari referensi melalui berbagai sumber khususnya melalui google, kami membaca bahwa pada tanaman karamunting terkandung beberapa senyawa metabolit sekunder diantaranya adalah tanin.<smiles>O=c1c(O)c(-c2ccc(O)c(O)c2)oc2cc(O)ccc12</smiles>

Tanin merupakan bahan pewarna pada tumbuhan yang banyak tersebar luas pada tanaman, seperti akar, daun, buah yang belum matang serta di kulit kayu. Karena itulah kami mencoba memanfaatkan senyawa tanin khususnya pada bagian daun Karamunting sebagai bahan baku untuk membuat tinta isi ulang spidol.

Pemanfaatan bahan alami daun Karamunting (Rhodomyrtus tomentosa) sebagai bahan baku tinta isi ulang spidol masih belum dikembangkan. Penelitian ini bertujuan untuk memanfaatkan daun Karamunting (Rhodomyrtus tomentosa) sebagai bahan baku tinta isi ulang spidol. Hasil penelitian ini dapat meningkatkan pemanfaatan daun Karamunting (Rhodomyrtus tomentosa) menjadi produk yang bernilai dan memberikan nilai tambah pada daun Karamunting (Rhodomyrtus tomentosa).

\section{METODE PENELITIAN}

Metode penelitian yang kami gunakan adalah metode eksperimen dengan cara membandingkan 3 sampel ekstrak daun Karamunting (Rhodomyrtus tomentosa). Penelitian dilaksanakan sejak tanggal 6 sampai 5 September 2017 di Laboratorium IPA SMAN 1 Cempaga.

\section{Alat dan Bahan Penelitian}

a. Alat yang digunakan adalah blender, panci, gelas beker, saringan, pengaduk, kaki tiga, bunsen, spatula dan pipet.

b. Bahan yang digunakan adalah ekstrak daun Karamunting (Rhodomyrtus tomentosa), cuka, tepung kanji, dan paku berkarat.

\section{Langkah Kerja}

1. Membuat ekstrak daun Karamunting (Rhodomyrtus tomentosa) dengan cara memblender daunnya sampai halus lalu mencampur dengan sedikit air kemudian menyaringnya. 
2. Membiarkan ekstrak daun Karamunting (Rhodomyrtus tomentosa) tersebut selama 1 jam agar didapatkan endapannya.

3. Memisahkan endapan dan bagian atas ekstrak daun Karamunting (Rhodomyrtus tomentosa) sehingga diperoleh 3 macam sampel.

4. Merebus 3 macam sampel ekstrak daun Karamunting (Rhodomyrtus tomentosa) tersebut sampai mendidih.

5. Mencampur rebusan yang sudah dingin tersebut dengan paku berkarat, tepung kanji, dan cuka.

6. Membiarkan campuran tersebut selama 1 malam agar didapatkan campuran hitam pekat yang akan digunakan sebagai bahan baku tinta.

7. Membandingkan hasil ketiga sampel tersebut.

\section{HASIL PENELITIAN DAN PEMBAHASAN}

Daun Karamunting (Rhodomyrtus tomentosa) yang telah dicuci bersih diekstrak dengan cara diblender sampai halus dengan menambahkan sedikit air. Penambahan air untuk melarutkan tanin karena tanin akan membentuk koloid ketika dicampur dengan air. Hasil blenderan tersebut dipisahkan ke dalam 2 gelas kimia. Gelas pertama berisi ekstrak yang telah disaring agar terpisah dengan ampasnya, sedangkan gelas kedua berisi ekstrak yang tidak disaring. Ekstrak pada gelas pertama dibiarkan selama 1 jam agar terpisah antara air dengan endapannya. Setelah satu jam, air dan endapan tersebut dipisahkan dan dimasukkan ke dalam 2 gelas kimia yang berbeda kemudian direbus sampai mendidih agar kadar airnya berkurang.

Rebusan ketiga sampel tersebut didiamkan sampai dingin, kemudian dicampurkan dengan tepung kanji. Hal ini dilakukan agar tepung kanji tidak masak karena rebusan yang masih panas. Tepung kanji ditambahkan untuk mengentalkan rebusan sampel tersebut. Kemudian campuran tersebut ditambahkan paku berkarat dan cuka. Paku berkarat berperan untuk menghitamkan warna rebusan karena dalam paku berkarat terdapat senyawa CMC (carboxymethyl cellulose) sedangkan cuka digunakan untuk melarutkan CMC. Sampel tersebut kemudian dibiarkan selama 1 jam agar warna yang dihasilkan menjadi maksimal.

Dari hasil pencampuran dapat dilihat zat warna hitam yang dihasilkan dari ketiga sampel daun Karamunting tersebut. Sampel 2 yaitu endapan ekstrak daun Karamunting menghasilkan warna yang lebih hitam pekat dibandingkan dengan sampel 1 dan 3. Hal ini dilihat melalui uji organoleptik yaitu melihat warna yang dihasilkan dan daya serap ketika dituliskan pada kertas. Wa

Sampel 2 menghasilkan warna hitam yang lebih pekat karena sampel 2 merupakan endapan ekstrak daun Karamunting. Kandungan tanin lebih banyak dalam sampel 2 karena yang diambil hanya endapannya saja.

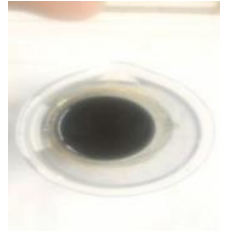

1

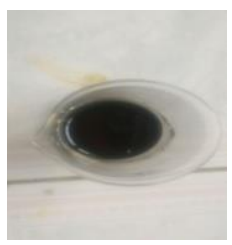

2

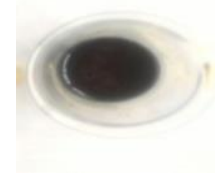

3 


\section{SIMPULAN}

Pemanfaatan daun Karamunting sebagai bahan baku tinta spidol dapat dilakukan. Dari pencampuran 3 sampel daun Karamunting didapatkan warna yang lebih hitam pekat pada sampel 2 yaitu rebusan endapan ekstrak daun Karamunting dengan tepung kanji, paku berkarat, dan cuka.

\section{DAFTAR RUJUKAN}

Detiknews. (2017). Dua Pelajar Ini Ciptakan Tinta Spidol dari Daun Jambu Biji. Diperoleh dari 9 April 2017, dari https://m.detik.com

KALANGKABUT. (2013). Karamunting. Diperoleh 6 April 2017,dari http://indo-pos.blogspot.com/2013/04/karamunting-octhocharis-bornensisbl.htm/m\%3D1\&ei=v8JQ1mmy\&lc=idID\&s=1\&m=764\&host=www.google.co.id\&ts=1507253326\&sig=ANTY_L3 _HWPLNiY 31D3k94woTIQQInlaA

Devi,dkk. 2016. Kesetimbangan Kimia Unsur. Jakarta : Kementrian Pendidikan dan Kebudayaan. 